\title{
平板試料の二軸引張試験機*
}

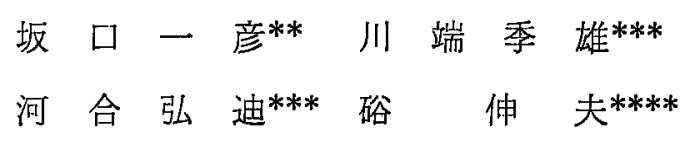

\section{Biaxial Tensile Tester for Flat Plates}

\author{
by \\ Kazuhiko Sakaguchi, \\ (Faculty of Engineering, Doshisha University, Kyoto) \\ Sueo Kawabata, Hiromichi Kawai, \\ (Faculty of Engineering, Kyoto University, Kyoto) \\ and Nobuo HAZAma \\ (Toyota Automotive Industry Co., Ltd., Toyota)
}

\begin{abstract}
A new type of biaxial tensile tester for flat plates has been produced, which can make uniform extention of a square plate in biaxial directions. The tensile mechanism of this tester consists of two servomechanism for the control of the position of the two travelling beams on which cramp chacks are mounted. These chacks are capable of easy travelling on the beam surface by means of ball bearings. By the use of this tester it is made possible to perform such testing as tensile testing, stress relaxation measurement, creep testing and fracture strength testing, under homogeneous biaxial stress states.

In this paper the mechanism of this tester is described, and the results of elastic property measurements of BR, SBR, and IR rubber sheets using this tester are reported. The load-elongation diagrams are obtained by this tester and energy function are calculated from it as a function of invarients $I_{1}, I_{2}$ of deformation tensor.

(Received Dec. 11, 1967)
\end{abstract}

\section{1 緒 言}

エラストマーの上うな大変形可能な高分子物質の力 学的特性の試験は，普通は一軸引張試験によって行な われているが，理論的には二軸および三軸の応力下で の力学的特性を求めないかぎり完全な力学的定数を得 ることはできないまた実際のこうした材料の使用状 沉をみてもむしろ二軸応力, すなわち平面応力状態が 普通である。したがって，二軸応力下における材料の 力学特性や強度特性を得ることが重要になるが，従来 から試験はほとんど一軸引張りによって行なわれてい る状態で，この試験結果から大变形下すなわち非線型 的な二軸応力下で力学挙動を推定することは不可能で あり，ま七て二軸応力下での強度はなおさらである。

二軸応力状態をつくる試験は従来からいろいろの方 式が報告されている。 また平板状の試料に対する二軸
* 原碚受理 昭和42年12月11日

** 正会員 同志社大学工学部 京都市上京区今出川通鳥丸東

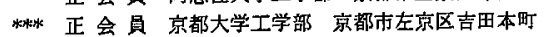

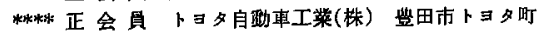

引張試験についても二, 三報告されているが，大変形 可能な物質に均等ひずみを加えて，その力学的性質を 測定したり，強度特性を得るには不充分であると考え られる、そこで著者らは，このような物質の平板試料 を用いて材料の力学的性質を正しく評価するために, 試料に直角二方向から均等ひずみを加える二軸引張試 験機を試作した．本試駼機は二軸方向の定速引張り， 応力緩和およびクリープ測定などが可能である. 本報 においては試験機の概要と二, 三の測定例につけて記 述する。

\section{2 試験機の原理および概要}

\section{$2 \cdot 1$ 原理および機構}

試験機は試料に引張変形を加える引張機構と，直角 二朝方向のそれぞれの荷重检出機構, および引張りの 制御部, 荷重から電圧への变換装置および記録装置か ら棈成されている。

Fig. 1 に本試験機の主要部の機構, Fig. 2 に主要部 の外観を示す. 試料は 4 個の荷重受バーで保持され， 


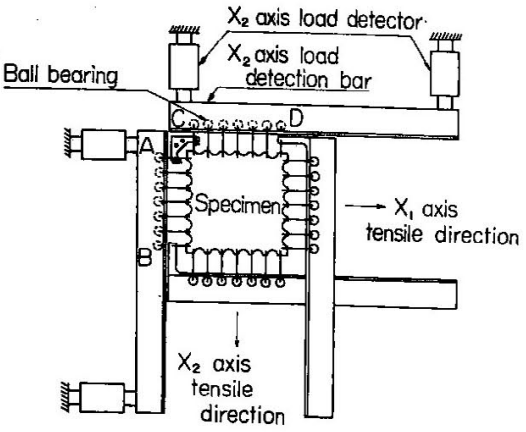

Fig. 1. Mechanism of the biaxial tensile tester.

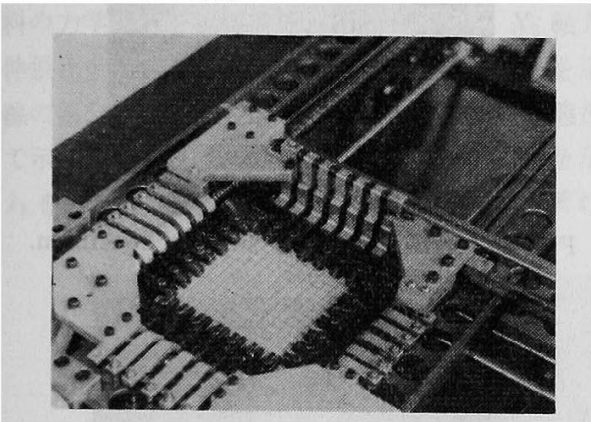

Fig. 2. Appearance of the biaxial tensile tester.

うち 2 個のバーは荷重検出のため固定され，他の 2 個 は試料に变形を与えるため移動できる移動用バーであ る.移動用バーはそれぞれのサーボモータに上り駆動 され， $x_{1}, x_{2}$ 軸方向にそれのぞれ命令電压に従って移 動する. 正方形の平板試料は一辺 7 個ずつ, 全周辺で 28個のチャックでクランプされ，試料取付操作は容易 にできるようにチャックの構造を設計した。 また，千 ヤックの試料把持部は, 試料が伸張変形を受けるにつ れて生ずる引張力により把持力を高める，いわ吼 ルフタイト方式をとった。チャックフームの他端はホ犬 一ルベフリングが取り付沽られ，荷重受バ一上をなめ らかに移動するようにした。サーボモータによって移 動用:ーが移動すると，試料の伸張につれて移動用ハ 一上をボールベアリングの回転でチャックアームが移 動して，試料に直角二方向から均等ひずみを与えるよ うにした，本試験機は試料にこのような均等ひずみを 加える方式を採用しているため，後述する理由により， 各辺の両端部のチャックは荷重検出ベーから分離し， 5 個のチャックから荷重を検出している。 また，Fig. 1に示す $\mathrm{A}, \mathrm{B}, \mathrm{C}$ およびDのチャックからも荷重を検 出することができる。

試料の伸張につれてチャックの位置が移動するため， 試料の一辺にかかる荷重は, 各軸方向についてそれぞ れの荷重検出パーの両端に設けた 2 個の荷重検出器か らの和の信号として次に述へるように検出し，記録す
るようになっている。

\section{2. 荷重検出原理}

荷重検出器は力を差動変王器によって検出する㻴状 力計を用いた。これは荷重範囲の変更による力計の交 換をなるぺくなくするため，同じ力計でフルスケール $2 \mathrm{~kg}$ から $200 \mathrm{~kg}$ まで選択できるようにしたが，こ れはリング式と差動変圧器の組合せで可能になる。特 に, 差動変压器の材質については周囲の熱的環境条件 による変動をできるだけ小さくするよう考慮した，前 述のように，試料の伸張につれチャックが移動し加重 点が移動するため, 2 個の荷重検出器を荷重検出バー の両端に設置した．Fig. 3 に示すようにA点(移動点)

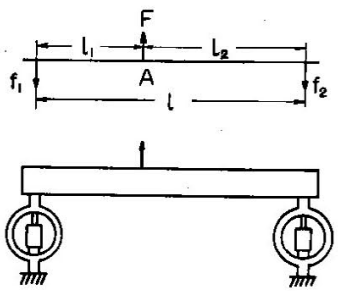

Fig. 3. Detection method of travelling load.

に作用する一つの力を $F$, バーの全長を $l, \mathrm{~A}$ 点から両 端までの距離を $l_{1}, l_{2}$ とし，両端部すなわち検出器に 作用する力を $f_{1}, f_{2}$ とすると

$$
\begin{gathered}
f_{1}=\frac{F l_{2}}{l}, f_{2}=\frac{F l_{1}}{l} \\
\therefore f_{1}+f_{2}=F
\end{gathered}
$$

となる、A 点に作用するカが検出バー上のどの位置に 移動しても荷重検出器に作用する力の和 $\left(f_{1}+f_{2}\right)$ は一 定 $F$ を示す

\section{$\mathbf{2} \cdot \mathbf{3}$ 測 定 機 能}

Fig. 4 は全体のブロックダイヤグラムを示す．試料

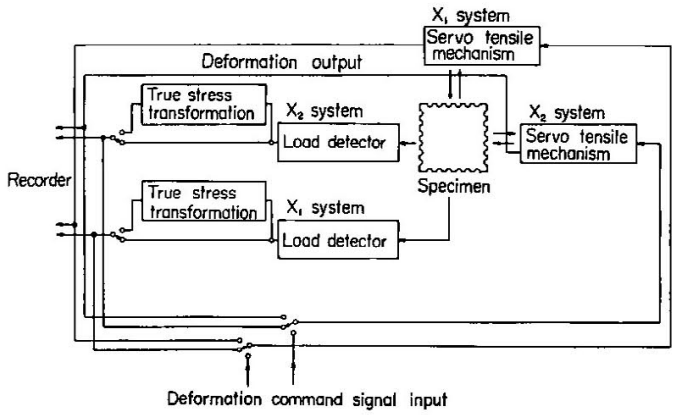

Fig. 4. Blockdiagram of the biaxial tensile tester.

に変形を与える引張機構は $x_{1}, x_{2}$ 軸ともに電圧を入 カとし，移動用バーの位置を出力とするサーホ機構に なっておりここのため外部からの命令信号に従って試 料に引張変形をその命令どおりに与えることが可能て 
ある、したがって，たとえば二軸方向への異なった比 率での定速引張試験，また二軸方向の各荷重を一定に 保つように試料に変形を与える(クリープ試験)ことも 可能で，また試料の体積一定を仮定して荷重を真応力 に変換したクリープ試験もできるようにした，そのほ かに応力緩和測定, 二軸破垣強度も容易に測定が可能 である。

\section{3 試験機の特性および性能}

Fig. 5 にサーボ機棈の周波数応答特性を示すボーデ 線図を示す， $x_{1}, x_{2}$ 軸とも同じ状態である。

Fig. 6 は荷重検出バーに静荷重を加え，荷重検出器 の較正曲線を示す。荷重検出パーは $200 \mathrm{~kg}$ まで荷 重の検出ができるよう設計している，交換器の感度は 5 段切換えとし，2，6，20，60 および $200 \mathrm{~kg}$ フルスケ ールとしている.

試料形状はモールド可能な材料に対しては，Fig. 7 に示すように，周辺部を補強したものを用いた。 また，

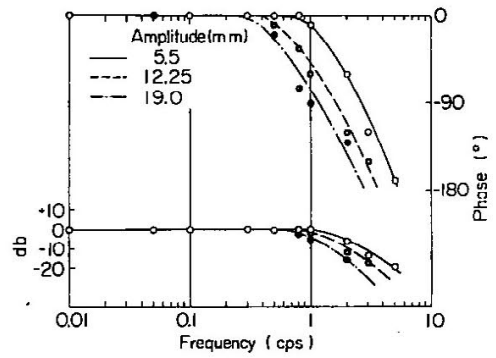

Fig. 5. Frequency response of the servomechanism.

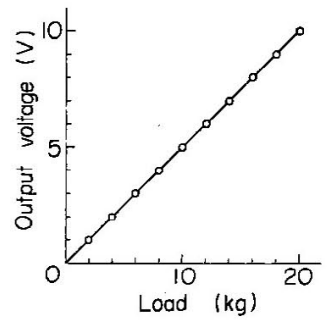

Fig. 6. Calibration curve of load detector.

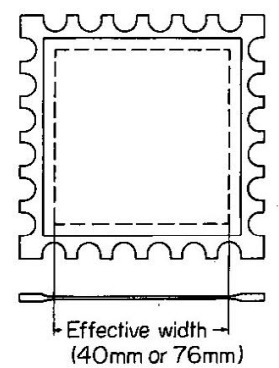

Fig. 7. Shape of specimen.
周辺部を補強しない陚料，すなわち，平板より切り取 った陚料に対しては四隅のチャック間の距離を内部チ ヤック間の距離より大さく取り, 試料有効長さを小さ くする，試料形状に関する問題は試験中の試料の変形 状態を検討することによって明碓となる.

本試験機は均等ひずみを与える方式をとっているた め，その均等性についての検討を必要とする。 Fig. 8

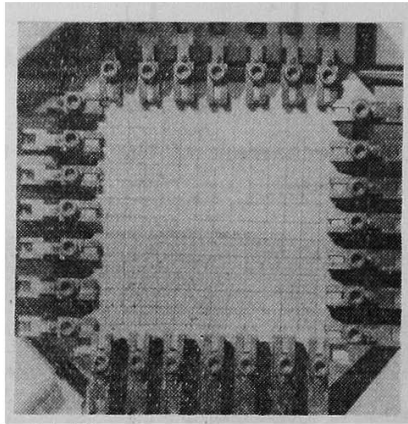

Fig. 8. (a) Undeformed state of specimen.

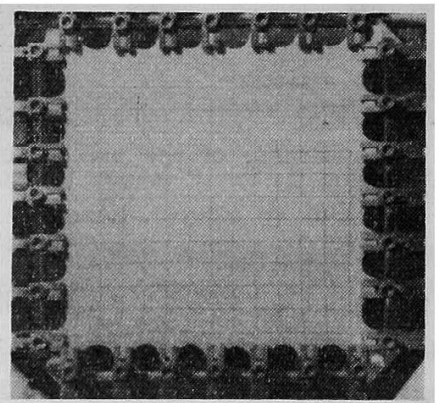

Fig. 8. (b) Deformed state of specimen stretch ratio $\lambda_{1}=\lambda_{2}=1.5$.

に示すように試料に格子を描き，伸張時の変形状態を 写真撮影した. (a)は変形前, (b)は変形後の状態 $\left(\lambda_{1}=\right.$ $\left.\lambda_{2}=1.5\right)$ を示す，図から明らかなように，試料の周辺 部において変形状態はやや乱れている。したがって， 荷重の検出はこの周辺部の乱れを避けるため, 前述の 上うに荷重㭘出ハー一側の両端チャックを荷重検出ハー から分離し， 5 個のチャックの力を検出する，それぞ れのチャックにかかる力を検討した結果，ほとんど均 一であることが確認された，したがって，Fig. 7 に示 すように試料有效長さをとることとする．

$X_{1}, X_{2}$ 軸から検出される荷重を記録するために， マルチパイブレータとリレーを組み合わせて自動（手 動も可) 切換装置を試作した。単チャネルレコーダに 上り容易に $X_{1} ， X_{2}$ 軸の荷重を同時記録することが可 能である，その上切換時間を適当に選ぶことができる．

\section{4 測定結果および考察}

応用測定例として，BR(ブタジェンゴム), SBR(ス チレンブタジェンゴム)および IR(イソプレンゴム)を プレスで圧縮加硫成形した試料を用いた二軸定速引張 
Uniform bi-axial tensile

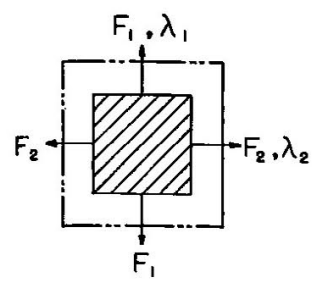

Strip bi-axial tensile

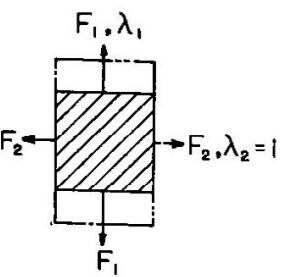

( $F:$ Load, $\lambda:$ Stretch ratio)

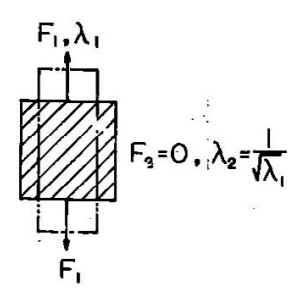

Fig. 9. Some different types of tensile testing.

試験による結果について記述する， $X_{1} ， X_{2}$ 軸の伸張 比をそれぞれ異にした場合の荷重一伸び線図を求め, 材料の力学定数を決定する. Fig. 9 は $X_{1}, X_{2}$ 軸方向 の伸張比を異にした場合の荷重と伸張比の関係を示す. 斜線の部分は変形前の形状を示し, 变形後の状熊を鎖 線で示す，添字 1,2 はそれぞれ $X_{1}, X_{2}$ 軸方向を示し， $\lambda_{1}, \lambda_{2}$ をそれぞれの伸張比とし， $F_{1}, F_{2}$ をそれぞれの

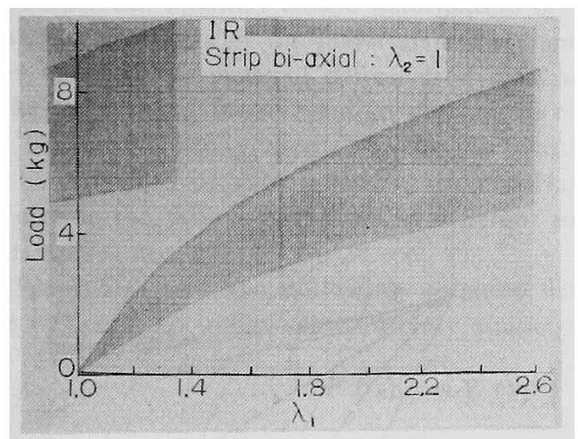

(a) $F_{1}$ and $F_{2}$ are recorded on same chart by electronic switching where the upper rim of the band is $F_{1}$ and the lower is $F_{2}$.

荷重とする。一般に $X_{1}, X_{2}$ 軸方向の 伸張比を等しくした場合を均等二軸引 張り (Uniform biaxial tensile), $X_{1}$ 軸方向に伸張し， $X_{2}$ 軸方向の伸張は 零，すなわち，常に変形前の長さを保 つ場合をストリップ二軸引張り (Strip biaxial tensile), $X_{\mathrm{I}}$ 軸方向に伸張し， $X_{2}$ 軸方向の力を零にした場合を一軸 引張り (Uni-axial tensile) と呼び, こ れらの伸張比のほかにも異なる伸張比 の組合せで実験を行なったが，得られた荷重一伸び線 四の一例を Fig. 10 (a), (b) に示す. $X_{1}, X_{2}$ 軸の荷重 は一定時間ごとに自動切り換えされ記録されている. 伸張比は $X_{1}$ 軸の値のみが現われているが， $X_{2}$ 軸の伸 張比は両軸の伸張の㓶合をあらかじめ設定しているた めに容易に算出できる。

力学定数を二軸試験によって得られた荷重一伸び線

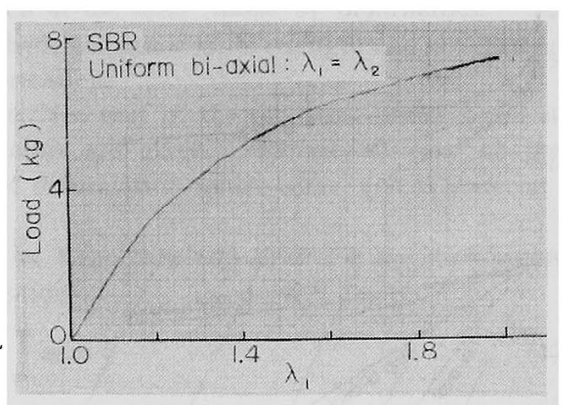

(b) $F_{1}$ and $F_{2}$ are on a same line because the material is homogeneous and isotropic.

Fig. 10. Load-stretch ratio diagram.

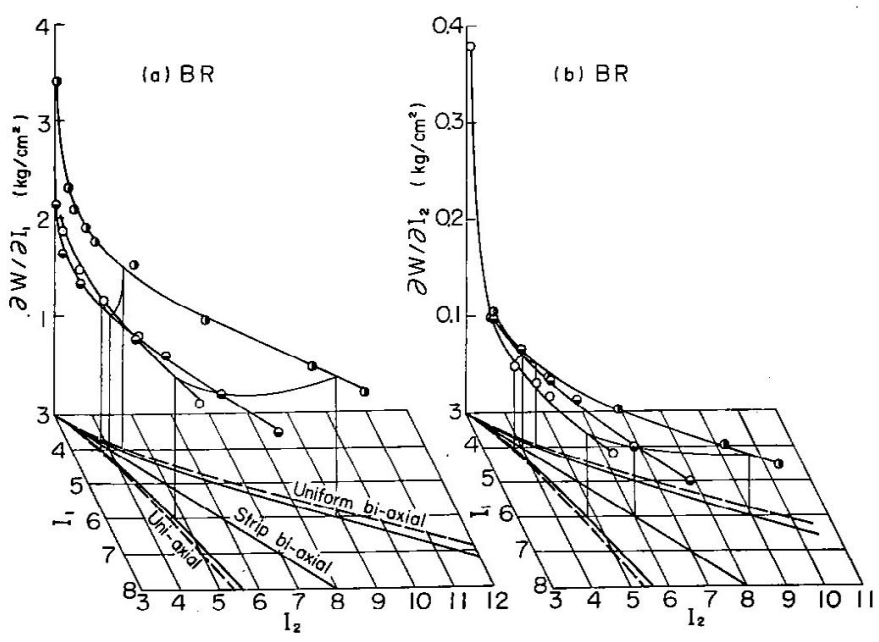

Fig. 11. (a) Measured $\partial W / \partial I_{1}\left(I_{1}\right.$, $I_{2}$ ) for the BR test specimen.
Fig. 11. (b) Measured $\partial W / \partial I_{2}$ $\left(I_{1}, I_{2}\right)$ for the BR test specimen.
四より算出するが，ここで材料を完全 弾性体，均一系，等方性および非圧縮 性と仮定して，線図より得られた荷重 と伸張比との関係より，次式が成立す 4)5)

$$
\begin{array}{r}
F_{1}=2 \frac{H}{\lambda_{1}}\left(\lambda_{1}{ }^{2}-\frac{1}{\lambda_{1}{ }^{2} \lambda_{2}{ }^{2}}\right) \\
\times\left(\frac{\partial W}{\partial I_{1}}+\lambda_{2}{ }^{2} \frac{\partial W}{\partial I_{2}}\right) \\
F_{2}=2 \frac{H}{\lambda_{2}}\left(\lambda_{2}{ }^{2}-\frac{1}{\lambda_{1}{ }^{2} \lambda_{2}{ }^{2}}\right) \\
\times\left(\frac{\partial W}{\partial I_{1}}+\lambda_{1}{ }^{2} \frac{\partial W}{\partial I_{2}}\right)
\end{array}
$$

ただし，

$\lambda_{1} \lambda_{2}:$ 伸張比 $(=1+\varepsilon, \varepsilon:$ ひずみ)

$F_{1}, F_{2}$ : 変形前の有効長さあたりの 荷重

$H$ : 変形前の試料の厚み 
$I_{1}, I_{2}:$ 変形テンソルの不変量 （非匤縮性物質では

$$
\begin{aligned}
& I_{1}=\lambda_{1}{ }^{2}+\lambda_{2}{ }^{2}+\frac{1}{\lambda_{1}{ }^{2} \lambda_{2}{ }^{2}}, \\
& \left.I_{2}=\frac{1}{\lambda_{1}{ }^{2}}+\frac{1}{\lambda_{2}{ }^{2}}+\lambda_{1}{ }^{2} \lambda_{2}{ }^{2}\right)
\end{aligned}
$$

$W:$ 変形によって生ずるひずみ エネルギ

$\partial W / \partial I_{1}, \partial W / \partial I_{2}$ は材料の力学定数を 示し，上武に測定した力成分 $F_{1}, F_{2}$ を代入して容易に算出できる。

$\mathrm{BR}, \mathrm{SBR}$ および IR について $I_{1}, I_{2}$ と $\partial W / \partial I_{1}, \partial W / \partial I_{2}$ の関係を图示する と Fig. 11 (a), (b), Fig. 12 (a), (b) お よび Fig. 13 (a)，(b) が得られる。こ の曲面から材料のそれぞれの伸張時の 定数が明確になる。 $\partial W / \partial I_{1}, \partial W / \partial I_{2}$

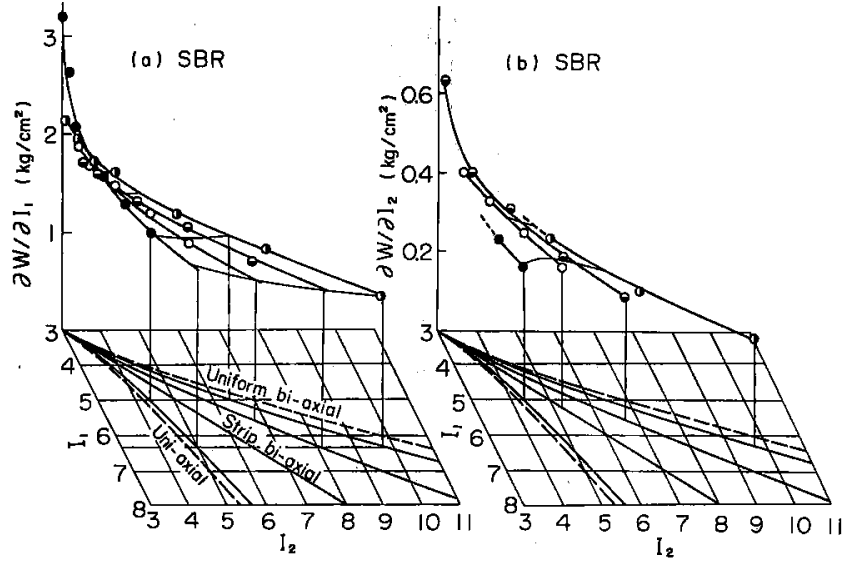

Fig. 12. (a) Measured $\partial W / \partial I_{1}$ $\left(I_{1}, I_{2}\right)$ for the SBR test specimen.
Fig. 12. (b) Measured $\partial W / \partial I_{2}$ $\left(I_{1}, I_{2}\right)$ for the SBR test specimen.

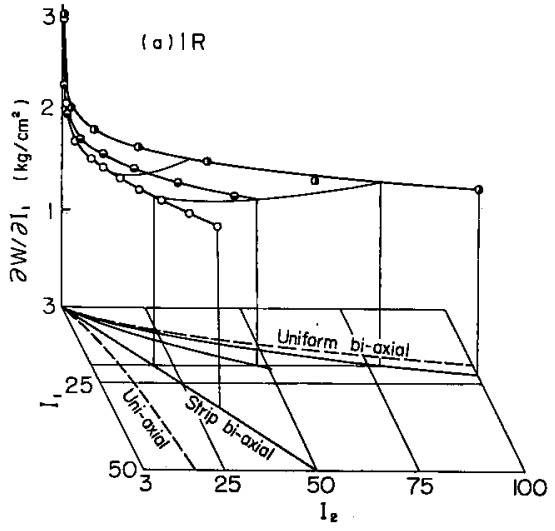

Fig. 13. (a) Measured $\partial W / \partial I_{1}\left(I_{1}, I_{2}\right)$ for the IR test specimen.

はともに $I_{1}, I_{2}$ が大になるに從って減少し，減少率は $\partial W / \partial I_{1}$ より $\partial W / \partial I_{2}$ が大である。

\section{5 結言}

以上試作した平板用の二軸引張試験機の構造および 性能について記述した，特に，試料に均等ひずみを与 える方式を採用しているため，その均等性については 試験中における変形状熊を記録撮影することによって 満足できる均等性が得られていることを確認できた。 本試験によって，(a)二軸定速引張試験，(b)二軸応力緩 和試験，(c)二軸クリーブ試験および，(d)二軸破壊強度 試験など各種試験が可能である。

BR， SBR および IR を用いて力学定数を决定する ため材料を完全弾性体，均一系，等方性および非圧縮 性と仮定し，荷重一伸び線㘡より得られた荷重および 伸張比より算出したエネルギ関数を，变形テンソルの 不変量 $I_{1}, I_{2}$ の関数として图示し, $\partial W / \partial I_{1}, \partial W / \partial I_{2}$

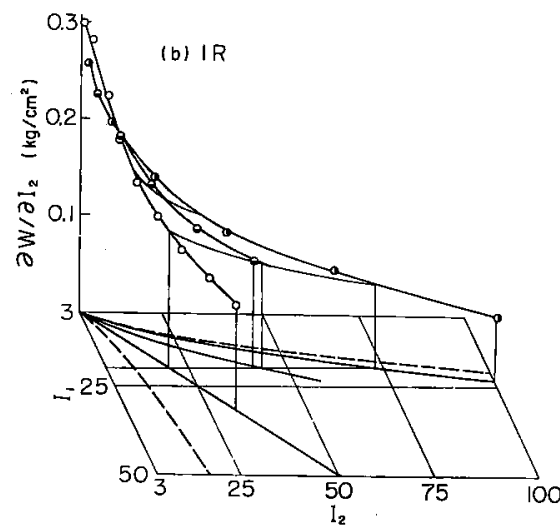

Fig. 13. (b) Measured $\partial W / \partial I_{2}\left(I_{1}, I_{2}\right)$ for the IR test specimen.

の曲面を得た．この曲面より任意の伸張時の $\partial W / \partial I_{1}$, $\partial W / \partial I_{2}$ が明らかとなった。これらの定数は一軸引張 試験によって求まらないものである.

最後に本試験機の製作に対してご協力いただいた岩 本製作所に対して感謝する。

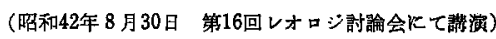

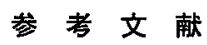

1) Naghdi, P.M., and J.C. Rowly, J. Mech. Phy. Solid, 3 (1954)

2) Sharma, M.G., SPE Trans., 6, No. 1, (1966).

3）白鳥英完，池上䗢三，材料，16，165 (1967).

4) Rivlin, R.S., and D.W., Saunders, Philos. Trans. Roy. Soc. London, A 243 (1951).

5) Eringen, A.C., Nonlinear Theory of Continuous Media, Chap. 6 (1962) McGraw-Hill Co., New York. 